\title{
Parameterization of apparatus TELIT
}

Bílek David, Skrbek Břetislav

Katedra materiálu KMT, Technická univerzita v Liberci, Studentská 2, 46117 Liberec 1.

E-mail: david.bilek@tul.cz, bretislav.skrbek@tul.cz

Nowadays every reliable activity simplification leading to time saving is an important positive. The constraint of customers to documentation of mechanical properties just on castings is everlasting. It can be achieved without submission of casting to destructive testing, by non-destructive structuroscopy. This contribution describes the possibility of non-destructive determination of ultimate tensile strength of castings of graphite cast irons using TELIT structuroscope and parametrization of mathematical model for non-destructively determined strength using this instrument.

Keywords: Structuroscopy, shape of graphite, strength, cast iron

\section{References}

[1] BÍLEK, D. Výzkum tloušt'koměru DIO 570 v ultrazvukové strukturoskopii litin. TU v Liberci, 2006.

[2] OBRAZ, J. Zkoušení materiálu ultrazvukem. SNTL Praha, 1976.

[3] SKRBEK, B. Nedestruktivní materiálová diagnostika litinových odlitků. Disertační práce, VŠST Liberec, 1988.

[4] SKRBEK, B., NOSEK, V. Lokální magnetická strukturoskopie, vliv kvality povrchu na výsledku. Konference Defektoskopia 2005.

[5] Projekt F1 - 1.M/001. Výzkum a zavedení výroby odlitků metodou INMOLD pro BONATRANS. Dílčí zprávy, např. Kombinovaný strukturoskop TELIT - 1. Technický popis a návod k obsluze. ELKOSO s.r.o. Brno, 2006.

[6] NETÁHLO, P. Měření metodou magnetického bodového pólu na tenkých stěnách ocelí a litin. TU v Liberci, 2006.

[7] FLANDERKA, M. Magnetická strukturoskopie netryskaných výkovků a odlitků. TU v Liberci, 2008.

[8] HOLEŠOVSKÝ, F., ŠKARDA J. Pokyny pro autory článků do časopisu Strojírenská technologie. Strojírenská technologie, 2007, roč. 12, č. 1, s. 31-33. ISSN 1211-4162.

[9] HOLEŠOVSKÝ F. Technické vzdělávání jako služba společnosti. In Strojírenská technologie. 2009, roč. 14, č. 2, s. 39-42. ISSN 1211-4162. 